\title{
Клинична и диференциално-диагностична характеристика на ангината и нейното място като спешно състояние
}

\author{
Д. Конов \\ УМБАЛ „ Царица Йоанна-ИСУЛ“, Клиника по УНГ-болести
}

\section{Резюме:}

Ангината е остро самостоятелно бактериално или вирусно заболяване, което може да се изяви и като симптом на друго инфекциозно или системно заболяване. Под формата си на самостоятелно заболяване се свързва най-често със стрептококова инфекция и е в причинно-следствена връзка с острия ставен ревматизьм. В този обзор ние представяме основните ѝ клинични и диференциално-диагностични характеристики, както и мястото на това заболяване в спешната помощ.

\begin{abstract}
:
Tonsillitis is an acute bacterial or viral infection of the tonsils that can be primary or a symptom of other infectious or systematic disease. The most common primary tonsillitis is caused by a streptococcus agent and is in a consequent linkage with rheumatism. In this review we scope on the clinical characteristics and differential-diagnosis of the tonsillitis, as also its role as an emergency condition.
\end{abstract}

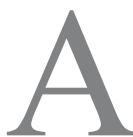
нгината е остро самостоятелно бактериално или вирусно заболяване, което може да се изяви и като симптом на друго инфекциозно или системно заболяване. Под формата си на самостоятелно заболяване се свързва най-често със стрептококова инфекция и е в причинно-следствена връзка с острия ставен ревматизъм.

\section{Клинична диагноза}

Клиничната диагноза се определя чрез най-характерните симптоми на ангината - дисфагия с одинофагия (болка при преглъщане, която често се успокоява след преминаване на хапката), общ токсоинфекциозен синдром - треска, главоболие, обща отпадналост, болки в мускулите и прочие. Необходимо е да се уточни, че възпалението на тъканите на фаринкса и небните тонзили може да бъде едностранно, двустранно, с асиметрия във възпалителния процес, което се отразява и върху клиничната картина, съответно проявяваща се или с дифузност, или с асиметрия и предоминиране на една от страните.

\section{Класификация и диференциална диагноза}

Класически ангината според вида на възпалението се разделя на катарална, фоликуларна и лакунарна форма. Типичното за тях е, че налепите не преминават границите на сливиците и че всяка от формите може да прераства в другите. В диференциално-диагностичен план първата характеристика е 
много важна, тъй като при ангината при инфекциозна мононуклеоза налепите често излизат извън тези рамки. Допълнително е необходимо да се тьрсят и характерните за това заболяване генерализирана аденопатия, хепато-спленомегалия и обривен синдром. По-рядко срещана е улцеро-некротичната ангина на Plout-Vincent, която се проявява с типична едностранна улцерозна лезия в областта на едната от двете небни тонзили, различни по тежест оплаквания от общ характер и доминиращ лош дъх (foetor ex ore). Ангината при скарлатина се проявява с тъмночервени, едематозни тонзили, увула и фарингеална мукоза, както петнистия еритем на мекото небце и малиновия език. На този фон се наблюдават дебели белезникави плаки по сливиците с периорална бледост около устата, типичен обрив с трицевидно лющене на краиниците при оздравяването. При дифтерийната ангина, причинена от бактерия corynebacterium diphtheriae, налепите се сливат един с друг, понякога само върху тонзилите, но като правило преминаващи към съседните дъги, меко небце, увула. Постепенно налепите придобиват сивобелезникав цвят, като в началото се изтриват лесно, но бързо задебеляват, добре фиксирани към подлеващите тъкани, така че трудно се отделят и остават кървяща повърхност. Лимфните възли в региона са със значителен периаденит, фиксирани за съседните структури (Ив. Ценев, 2003). Необходимо е да се отбележи и синдромът на Лемиер - ангина, проявяваща се при белодробен инфаркт. Общото състояние е много тежко, като клиниката се владее от водещото заболяване.

\section{Изследвания}

Назначаването на изследванията се определя от наличната клинична картина, която насочва лекуващия лекар към вероятната диагноза. Стандартният гърлен секрет за антибиограма, макар с бавен резултат, остава изключително необходим, особено при трудни за лечение и рецидивиращи инфекции. Ние подкрепяме и използването на диагностични китове, откриващи бета-хемолитичен стрептокок (Home test s. Doctor test и др). При съмнения за инфекциозна мононуклеоза са необходими няколко параклинични изследвания. Чрез серологични тестове се откриват антитела към нуклеарния антиген (NA), към ранните антигени (EA) и към вирусния капсиден антиген (VCA). При първите симптоми на болестта се появяват IgM към ЕА и към VCA. Нараства и титърьт на IgG към двата антигена. IgM антителата във VCA имат диагностична стойност за заболяването. Те изчезват няколко месеца след оздравяване. В оздравителната фаза антителата към NA започват да се покачват и персистират в продължение на години. При 90\% от болните се установяват хетерофилни антитела. Те аглутинират овнешки или конски еритроцити, което се доказва чрез реакцията на Paul-Bunell. Хетерофилните антитела остават до 1 година след боледуване. За инфекциозната мононуклеоза са характерни атипични лимфоцити в периферната кръв, които представляват CD8 и CD4 Т-лимфоцити, а не вирусно инфектирани В-лимфоцити. Налице е левкоцитоза 10-20 х 109/1. В ДКК над 50\% са лимфоцити, като $10-20 \%$ са атипични лимфоцити. Серумните трансаминази и алкалната фосфатаза могат да се повишат 2-3 пьти. Чрез реакцията на Paul-Bunell се доказват хетерофилни антитела. Счита се за положителна при титър над $1: 80$. Позитивира се след първата седмица и остава положителна няколко седмици. Ако тази проба е отрицателна, се търсят антитела срещу вируса на Epstein-Barr: анти-VCA, анти-EA. Прясна инфекция с EBV се доказва с наличието на IgM анти-VCA.

\section{Етиологични агенти}

Сред най-честите вируси причинители на ангината са аденовирусите и Епщайн-Бар вирусьт, докато сред водещите бактериални причинители се нареждат на първо място бета-хемолитичният стрептокок, пневмококът, стафилококус ауреус и хемофилус инфлуенце. Причинител на ангината на Plout-Vincent е бактерият Spirocheta perfringens, а на дифтерията - Corynebacterium diphtheriae.

\section{Лечение}

Лечебната стратегия се определя от формата/ стадия и съответно от предполагаемия причинител на ангината. В катаралния стадий се препорьчва симптоматична терапия, купираща температурата и болката. При наличие на фоликуларна и лакунарна форма се налага антибиотично лечение, като антибиотици на първи избор са пеницилините и цефалоспорините. При съмнение за инфекциозна мононук- 
леоза не бива да се ползват пеницилини поради факта, че те провокират алергична реакция с характерен обрив по торса. Подходящо в тези случаи е и адитивна терапия с кортикостероиди по схема. Роля имат и локалните антисептици, особено важно е туширането на язвата при ангина на Венсан със слаб разтвор на сребърен нитрат (5\%). При наличие на алергия към бета-лактамни антибиотици избор на лечение са макролидите.

При ангина на Венсан е необходимо чрез биопсия да се изключи неопластичен процес, както и да се изключи агранулоцитозна язва.

\section{Алгоритьм за спешност}

Ние смятаме, че острото начало, бързото развитие на усложнения и тежкото общо състояние отреждат място на ангината, особено в някои нейни форми и при малки деца, на спешно състояние, изискващо преждевременно и бързо лечение. Според нас индикации за спешно състояние при ангина са внезапното начало, високата температура, генерализираният лимфаденит, детска възраст. При последния фактор особено бърза е дехидратацията, която утежнява сериозно общото състояние на децата, затова и при тях е необходимо бързо възстановяване на водно-електролитния баланс.

\section{Библиография}

1. STRUNSKI V. Angines, etiologies, diagnostic, evlution, traitement, Revue du Praticien 1993, 43: 2417-2420

2. Ценев, Клинико-морфологична риноларингология, 2003 г., стр. 374
3. К. Ле Пажолек. Практически аспекти на общата медицина, стр. 156,1998 г.

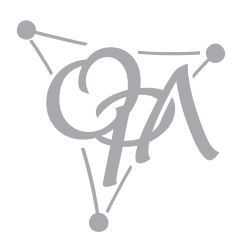

